\title{
Data Structure Teaching Reform Based on Computer Applied Talents Training
}

\author{
Wenfeng Chen
}

School of Information, Nanchang Institute of science \& Technology, Nanchang, 330108, China.

lunwenzju@163.com

\begin{abstract}
Data Structure is an important specialized course in computer applied talent training scheme. This paper has analyzed the existing problem of training the applied talent in data structure teaching. In views of the problem, this paper has proposed some improved measures from aspects of teaching content, teaching methods, teaching means and examination forms. The reform scheme can solve some problem of existing in the teaching of data structure to a certain extent, and meet to the need of applied talents better.
\end{abstract}

Keywords: Data structure; applied talents; teaching reform.

\section{Introduction}

The data structure is the subsequent course of programming, is also the basis of algorithm analysis and design, database principles and Applications, operating system, etc. For computer specialty, data structure is a basic and core course. Therefore, how to learn the data structure will became the key of training computer applied talents, while how to improve the learn internets, algorithm design, algorithm analysis and solve practice problem will become a important task of data structure teaching reform.

In recent years, many universities have studied on data structure teaching reform from teaching content, teaching method and teaching means. Han introduces ACM-ICPC training mode to practice teaching of data structure [1]. Qiu studies the practice teaching link, and proposes the corresponding the reform scheme [2]. Tang proposes "three step theory" method, and takes it to apply in the practice teaching of data structure [3]. Wei analyzes the teaching status of data structure, and proposes the teaching scheme based on project-driven [4]. There are some gaps between these results and the goal of training applied talents.

\section{The Necessity of Training the Applied Talents}

Understanding the need of employers is key to train applied talents. Educators should adjust teaching and education in accordance with the need of employers, so make the teaching form virtuous circle, which can really improve the teaching quality. Therefore, Nanchang Institute of science \& Technology had conducted questionnaires to 162 enterprises in 2014. Some 162 enterprises had filled in questionnaires about the need of employers and the ability of applied talents. The survey had retracted 128 validated questionnaires. We analyze these questionnaires. The results are shown in table 1.And we find out that most of employers are most serious about 3 professional knowledge and skills. These results are shown in table 2.

Table 1 Three professional knowledge and skills

\begin{tabular}{|c|c|c|}
\hline The Option Name & Percentage (\%) & Votes \\
\hline Specialty base knowledge & $55.44 \%$ & 70 \\
\hline Specialty core knowledge & 30.43 & 39 \\
\hline Specialty application skill & 73.48 & 95 \\
\hline Humanities and social knowledge & 47.66 & 61 \\
\hline Computer application skills & 38.28 & 49 \\
\hline Communication skills & 3.90 & 5 \\
\hline
\end{tabular}


Table 2 The talents type needed by employers

\begin{tabular}{|c|c|c|}
\hline The Option Name & Percentage (\%) & Votes \\
\hline Academic Talents & 10.15 & 13 \\
\hline Applied Talents & 87.05 & 112 \\
\hline Complex Talents & 2.34 & 3 \\
\hline
\end{tabular}

Table 1 and table 2 show that these employers are most serious about "specialty application skills" in five professional knowledge and skills. In the talents type needed by employers, $87.5 \%$ employers focus on "applied talents". Therefore, training applied talents is the top priority of Nanchang Institute of science \& Technology, and it is also for us to face problem of teaching reform of data structure.

\section{The Teaching Situation}

Data structure teaching plays an important role in training students solve practical problems by the programming skills, and is difficult to teach and learn. At the movement, most of universities and colleges main teach some knowledge of data storage and corresponding algorithms in data structure teaching. Most students are neither able to solve practice problem with algorithm thinking, nor able to design the corresponding the storage structure and algorithm for actual problem in life. In teaching of data structure, there are some problems [5, 6].

(1) The Poor Knowledge. The programming language is leading course of data structure, and is the first programming course to new students of computer science too. In addition, data structure has some difficult knowledge, such as point, function and structures, etc. Most students are difficult to adapt to the course with the knowledge of high school.

(2) The Unreasonable Teaching. The data structure some knowledge, such as linear list, stack, queue, tree, graph, sorting and searching. In addition, it is also consist of sequential storage, linked storage and its corresponding algorithm. In teaching process, many teachers spend much time in teaching theoretical knowledge, while shorten the hours of practice. The teaching method seriously obstructs the cultivating of the practical ability of the students. Students are difficult to digest the knowledge, and affect the course delivery, form vicious circle of teaching.

(3) The Unreasonable Teaching Methods. Most teachers have adapted the cultivating pattern that theory is prior to practice. Students cannot consolidate and deepen theory knowledge from practical training in real. In addition, teachers cannot react to homework of students in real, so it will lead to lose interest in learning it.

(4) The Unreasonable Learning Methods. Most students only can understand logic storage, physics storage and correspondig algorithms, while are difficult to implment the algorithm by programming lanaguage. When facing the practical problem, they only copycatt straight or search key on the internet. Very few students can implent these algorithms.

(5) The Unreasonable Examination Forms. In currently of the data structure teaching, most teachers still adopt the evaluation means of attendance and final examination. The examination means have disadvantage of single, one-sidedness and unfairness. These unavoidable problems are that we need to solve the problem in teaching reform of data structure.

\section{The Teaching Reform}

According to training goal of applied talents, the independent learning ability, algorithm analysis \&design ability, ability of solving practice problem, independent innovation ability and team collaboration ability are very important. So teachers should focus on these abilities in teaching of data structure, and gradually introduce logic storage, physical storage and corresponding algorithms, as so to improve students' programming ability, and cultivate the national needs of applied talent. This paper thinks that the old teaching mode of data structure should be broken, and should work out a practical scheme from teaching content, teaching method, teaching means and evaluation means in accordance with the actual situation of own university. 


\subsection{The Graphic Design needs to catch up with the Times.}

Aim for cultivating the modern enterprise needs have applied talent, we get in to deep into analysis to teaching content and study knowledge architecture what data structure should know and classify the knowledge into several different kinds. Our teaching teams divide teaching content of data structure into six big modules and nine small modules. And every small module is also divided into many algorithms and practical program. The teaching contents of data structure are shown in table 3 . We select the student achievement management system as practical project during the teaching reform of data structure, which cannot reduce students' strangeness and exclusion, but also introduce the practical problem into teaching reform of data structure.

Table 3 Teaching contents of data structure

\begin{tabular}{|c|c|c|}
\hline & Theory Knowledge & Practical Program \\
\hline \multirow{2}{*}{ linear list } & $\begin{array}{l}\text { Sequential storage and basic } \\
\text { algorithm }\end{array}$ & $\begin{array}{l}\text { student achievement management system } \\
\text { (The sequential storage) }\end{array}$ \\
\hline & $\begin{array}{l}\text { Linked storage and basic } \\
\text { algorithm }\end{array}$ & $\begin{array}{l}\text { student achievement management system } \\
\text { (The linked storage) }\end{array}$ \\
\hline \multirow{2}{*}{$\begin{array}{l}\text { Stack } \\
\text { and } \\
\text { queue }\end{array}$} & $\begin{array}{c}\text { Stack: the sequential storage, } \\
\text { linked storage and its basic } \\
\text { algorithm }\end{array}$ & $\begin{array}{l}\text { student achievement management system } \\
\text { (The stack) }\end{array}$ \\
\hline & $\begin{array}{c}\text { Queue: the sequential storage, } \\
\text { linked storage and its basic } \\
\text { algorithm }\end{array}$ & $\begin{array}{l}\text { student achievement management system } \\
\text { (The queue) }\end{array}$ \\
\hline \multirow{2}{*}{$\begin{array}{c}\text { Sorting and } \\
\text { searching(1) }\end{array}$} & $\begin{array}{l}\text { bubble sort, selection sort, } \\
\text { insertion sort, merge sort, } \\
\text { quickly sort, shell sort }\end{array}$ & $\begin{array}{l}\text { Sorting the part data of student } \\
\text { achievement management system }\end{array}$ \\
\hline & $\begin{array}{l}\text { Linear searching, } \\
\text { binary searching }\end{array}$ & $\begin{array}{l}\text { Searching the part data of student } \\
\text { achievement management system }\end{array}$ \\
\hline tree & $\begin{array}{l}\text { Tree, binary tree and its } \\
\text { corresponding algorithm }\end{array}$ & $\begin{array}{c}\text { student achievement management } \\
\text { system (The binary tree) }\end{array}$ \\
\hline graph & $\begin{array}{l}\text { The concept of graph, graph } \\
\text { storage and traversal algorithm }\end{array}$ & $\begin{array}{l}\text { student achievement management } \\
\text { system (The graph) }\end{array}$ \\
\hline Searching (2) & Binary searching & $\begin{array}{l}\text { Binary searching the part data of student } \\
\text { achievement management system }\end{array}$ \\
\hline
\end{tabular}

\subsection{The Teaching Methods and Teaching Means.}

We introduce the foreign advanced concept of engineering education (CDIO) into the teaching of data structure while making the teaching reform program, and implement teaching of data structure based on program. Before teaching knowledge of theory, we firstly propose needs of specific project, and lead students to analyze the actual problem. Then students solve the actual problem by using learned knowledge, so their learned knowledge is acquired of consolidating and deepening. During the course of project construction, teacher divides students into several groups, and every group membership needs complete requirements analysis, algorithm design, encoding, testing and running, so as to develop the students' ability to analyze and solve the problem.

Next, we explain by an example of linked storage of linear list. Before teaching the linked storage and its corresponding algorithms of linear list, teacher show off project needs of the module to students by projector. And teacher should also show off implemented projects to students, so as to promote students' interest. During teaching theory knowledge, teacher introduces basic algorithm practical training, so as to combine studying with practice, and explain some problems in real. After finishing teaching of linked storage and corresponding algorithms, teacher should assign some project practice for students to train. Students use their learning knowledge and corresponding algorithms to solve the practical problem. And cultivating applied talents accord with enterprise needs. 
During teaching, teachers can use resources of network platform, such as teaching outline for the course, courseware, teaching outline for the project and teaching case, etc. Students also hand in homework and talk over each other.

\subsection{The Evaluation Forms.}

According to "process evaluation" of the foreign advanced concept of engineering education (CDIO), we work out effective evaluation forms in accordance with the actual situation of data structure. The evaluation forms contain formative evaluation and End evaluation. The formative evaluation covers attendance, the level of activity and practical project (60\%). The end evaluation includes comprehensive practical project $(20 \%)$.

These comprehensive practical projects are relevant to practical problem, such as family tree system. According to teacher' requirements, students should implement the corresponding algorithms based on storage structure knowledge and corresponding algorithms, and talk over each other. During the last week, students need reply to their own projects. Teachers will take them as scoring of the end evaluation.

In evaluation of data structure, the impact of plagiarism detection cannot be avoided. If the plagiarism cannot be detected effectively, students' enthusiasm will be depressed. And the evaluation forms cannot really reflect reforms. Therefore, we need introduce the plagiarism detection system to teaching reform. It can not only ensure the fair evaluation, but also reduce teachers' workload.

\section{Summary}

The teaching practice in classroom has shown that the teaching reform scheme can not only improve learning interest of students, cultivate algorithm analysis ability, teaming and collaboration ability, but also teach students to solve the practical problem with learning storage structure and the corresponding algorithms. Next, we will further improve teaching reform of data structure in accordance with practical teaching situation. The successful teaching experiences can be employed in other courses, which has important realistic significance in implementing training scheme of whole applied talents.

\section{References}

[1]. HAN J M,ZHONG F Y,ZHAO X F. Exploring on the Practical Teaching of Data Structure Based on ACM-ICPC Training Mode. Computer Education, Vol. 10(2013) NO.10:103-107.

[2]. QIU Y Y, ZENG X Q. Reform and practice of Data Structure Course Construction of Application-oriented Universities. Journal of Jilin Institute of Education, Vol. 29(2013) NO.9:70-71.

[3]. TANG X J, WU X P, ZHOU C M. Study on Teaching Method of Data Structure Based on Training Practical Ability. Journal of Kaili University, Vol. 31(2013) NO.3:89-91.

[4]. WEI H J. The Teaching Reform of Data Structure Based on CDIO Engineering Concept. Neijiang Science and Technology, Vol. 1(2013) NO.1:69-70.

[5]. LI K Q. Exploring on the Case Teaching of Data Structure. Journal of Yangtze University (Natural Sciences), Vol. 4(2009) NO.6:135-136.

[6]. WANG H T. Exploring and Practice of Practical teaching of Data Structure. Computer Education, Vol. 16(2013) NO.8:55-57. 